and more particularly to the modernistic siyles of Marc Chagall (b. 1887) and Barys Małkin (b. 1908).

The achievements of this talented group of young artists are recorded in this collection, which includes an introductory note by I. Nazimava, brief biographical notes on more than 40 artists, and a number of selected illusirations from their works. Despite brave attempts to update their style, there is a sharp con'trast between the old protagonists of the socialist realisi school such as I. Davidovič, M. Hucijeŭ (b. 1912) and M. Bielski (b. $1921)$, and the younger artis'ts, some of whom, in particular $\mathrm{H}$. Papłaŭski (b. 1931), B. Zaboraŭ (b. 1935) and
V. and M. Basałyha (1940, 1942), show quite ou'tstanding ability. Clearly modern Byelorussian graphic art has come a long way since its hesitant beginnings in 1906, and one can en'tertain great hopes for its future.

It is unfortunate 'that the biographical notes are so brief, and that no particulars of the ar'ists' place of birth are given. In view of the considerable number of illustrations for books by Russian authors, one is left with the surmise that, to give the collection the prevailingly modish All-Union colour, more than just one or two non-Byelorussians may have been included.

\section{G. Picarda}

Łojka, A. A. Biełaruskaja paezija pačatku XX stahodździa. Niekatoryja zakanamiernaści i asablivaści. BDU, Minsk, 1972. 240 pages.

Professor Łojka is a prolific writer whose previous monographs include Adam Mićkievič $i$ biełaruskaja litaratura (1959), 'Novaja ziamla' Jakuba Kołasa (1961), Maksim Bahdanovič (1966), and Sustrečy $z$ dniom siońniašnym (a study of Soviet poetry: 1968). His latest book is devoted to the interval between the revolutions of 1905 and 1917 , or, perhaps more helpfully, the 'Naša Niva period' (1906-1915), and aims to reveal certain general tendencies (zakanamiernaści) and individual features of the poetry of the time.

The concept of zakanamiernaści in literary criticism is apt to send a cold shiver down bourgeois spines, and indeed many crimes of misinterpretation have been commi'cted in i's name. Łojka's confessed intent is to show 'the growth of Byelorussian poetry from concern for the peasant to concern for all humanity', and he pursues this course with ruthless albeit misguided determination in his analyses of Kupała, Kołas and Bahdanovič. This is particularly regrettable as the author himself is keenly aware of earlier travesties of criticism (vulharna-sacyjatahizatarskaja krytika) and is quick to attack his predecessors for their crude generalisations.

The book is in twelve parts, principally devoted to Kupała's 'Zalejka, Huslar and Slacham žyćcia, Kołas's Pieśni žalby, and Bahdanovič's
Vianok, but also includes sections on 'mass poetry' (short and shaky), 'poetry and folklore' (nothing new, except an unsuccessful attempt io treat Bahdanovič's vierš bietaruskaha sktadu from a thematic ra'cher than formal viewpoint), 'the establishment of a national (school of) transla'tion' (quite an interesting short analysis of Bahdanovič's efforts in this direction), and finally 'the search for a narrative poem'. The latter section typifies 'the book as a whole, for whilst providing a good detailed description of the movemen' of Kupała, Kołas and (in Łojka's view) Bahdanovič towards a paema and 'epic' style, the section is ruined by unnecessary generalisation, and particularly the assumption that the concept of narrative poem or epic is mysteriously but inex'iricably linked with heroism, national selfawareness, politics and revolution.

Bahdanovič, in one guise or another, takes up over half of 'the book, and yet he is the poet with whom Eojka seems least happy. He is ill served by the author's 'iortuous ideological manoeuvrings and frequent attempts to prove a negative; nor is there a great deal of new factual material to add to the earlier monograph. One 'new' revela'tion supposedly made in Polymia in 1958 (concerning Bahdanovič's views on Ziaziula: pp. 147-8) was in fact published by Anton $\mathrm{Na}-$ vina (Euckievič) in ' $\mathrm{Z}$ niedrukavanaje spadčyny pa M. Bahdanoviču', Hada- 
vik Bielaruskaha navukovaha tavarystva, 1 (1933). Other inaccuracies include the suggestion (p. 147) that the paper Bietarus began to be published in 1909, and that the references to Ziaziula came from an article of 1911 attacking it, whereas the first number of Bietarus appeared only in 1913.

In view of the profusion of existing books on the poetry of this period surely the richest in the whole of Byelorussian literature - it may be wondered whether there was need for another generalising study at all. However, the patient reader may find some interest in the analysis of individual books and phenomena, particularly in the sections dealing with Kupała and Kolas, provided he can disregard the book's obsession with thèse, and its conventionally rhetorical style, peppered with leaders and exclamation marks. There is no index, and the bibliography is laughingly described as in the footnotes'.

Arnold B. McMillin

McMillin, A. B. The Vocabulary of the Byelorussian Literary Language in the Nineteenth Century. The Anglo-Byelorussian Society, London, 1973. 336 pages.

This work, the author's doctoral thesis at the University of London, makes a significant contribution in a field which until recently had received scant attention from scholars of Byelorussian linguistics. The author himself, in a review published in JBS, II, 3, 1971, pp. 316-7, drew attention to this deficiency and it is therefore highly appropriate that he should have thus taken the initiative in attempting to rectify the situation.

After a bibliography of primary sources (i.e. the 19th-century tex's which form the basis of this study, some 120 in all), secondary sources, dictionaries and bibliographies, we come to the main body of the work, which consists of three sections: Part I, Introduction ( $\mathrm{pp}$. 26-44), Part II, Vocabulary (pp. 45-262) and Part III, Statistics and Conclusions (pp. 26389).

The Introduction contains a survey of lexicological and lexicographical work relating to the Byelorussian language of the 19th cen'tury. This is of necessity brief, since, as has been pointed out earlier, very little has been done in this field, and even in 'those works which have appeared the material studied has often been chosen on a highly selective basis. In addition research was for a long time seriously hampered by the inaccessibility of many primary sources, and this inevitably led to inaccuracies. Such criticisms certainly cannot be levelled at the author of the present work, which is based on an examination of all the printed and manuscript texts currently available.
Dr. McMillin next sets out the aims of his work. These are: to show the incidence and usage of individual words; to establish the first occurrence of each word; to show the relationship of the vocabulary of the 19thcentury language (in the broad sense of 'written language') to that of the Russian, Ukrainian and Polish literary languages and, in some measure, dialects; to attempt to ascertain the significance of geographical and other factors for individual writers and texts; to assess the use of Russicisms, Ukrainianisms, Polonisms and unrecorded forms; and finally to make some comparison between 'the 19thcentury literary vocabulary and that of the modern language.

The Introduction is concluded by an ou'tline of Byelorussian literature in the 19th century (previously published in JBS, II, 3, 1971, pp. 271-80), which gives biographical information about the authors and generally places them and their works in their historical context.

The Vocabulary comprises an examination of 3,378 words, which are grouped semantically according to the principles of Roget's Thesaurus. They represent in fact only abstract vocabulary, and although in the Introduction (p. 29) the author gives perfectly valid reasons for thus restricting the scope of his study, it would perhaps have been more accurate for the book to be entitled 'The Aibstract Vocabulary of the Byelorussian Literary Language in the Nineteenth Century', since with the present title anyone wishing to order 